\title{
Hyunsoonleella jejuensis gen. nov., sp. nov., a novel member of the family Flavobacteriaceae isolated from seawater
}

Correspondence

Duck-Chul Oh

duckoh@jejunu.ac.kr

\author{
Byoung-Jun Yoon, ${ }^{1} \dagger$ Dong-Heon Lee, ${ }^{1,2}$ † Bong-Jo Kang, ${ }^{3}$ \\ Hyung-Yeel Kahng, ${ }^{2}$ You-Sung Oh, ${ }^{1}$ Jung-Hoon Sohn, ${ }^{4}$ \\ Eui-Sung $\mathrm{Choi}^{4}$ and Duck-Chul $\mathrm{Oh}^{1}$
}
${ }^{1}$ Department of Biology, College of Natural Science, Jeju National University, Jeju 690-756, Republic of Korea
${ }^{2}$ Department of Environmental Education, Sunchon National University, Sunchon 540-742, Republic of Korea
${ }^{3}$ Jeju Province Fisheries Resources Research Institute, Jeju 699-915, Republic of Korea
${ }^{4}$ Laboratory System Microbiology Research Center, Korea Research Institute of Bioscience and Biotechnology (KRIBB), Daejeon 305-333, Republic of Korea

The family Flavobacteriaceae (Reichenbach, 1989; Bernardet et al., 2002; Bernardet \& Nakagawa, 2006) is one of the major phylogenetic lineages within the phylum Bacteroidetes (Garrity \& Holt, 2001). At the time of writing, the family comprises more than 50 recognized genera. Many members of this family were isolated from various marine ecosystems and Antarctic habitats (Bowman et al., 1997, 1998; Bowman, 2000; Bowman \& Nichols, 2002, 2005; Cho \& Giovannoni, 2004; Nedashkovskaya et al., 2004; Nichols et al., 2005; Pinhassi et al., 2006). Members of most genera in the family Flavobacteriaceae produce light- to bright-yellow pigments. These pigments may

†These authors contributed equally to this work.

The GenBank/EMBL/DDBJ accession number for the 16S rRNA gene sequence of strain $\mathrm{CNUOO4}^{\top}$ is EF217419. belong to the carotenoid and/or the flexirubin types depending on the genus (Bernardet et al., 2002).

Various bacteria are known to produce zeaxanthin, including Synechocystis sp. strain PCC 6803 (Lagarde et al., 2000), Erwinia herbicola (Hundle et al., 1993), Paracoccus zeaxanthinifaciens (Berry et al., 2003), Sphingobacterium multivorum (Alcantara \& Sanchez, 1999) and Zeaxanthinibacter enoshimensis (Asker et al., 2007). In the present study, we report the isolation, identification and characterization of a novel zeaxanthinproducing marine bacterium isolated from seawater.

Strain $\mathrm{CNU}_{004}{ }^{\mathrm{T}}$ was isolated from a seawater sample collected along the coastline of Jeju Island, Republic of Korea. Serially diluted seawater samples were spread on marine agar 2216 (MA; Difco) and incubated at $30{ }^{\circ} \mathrm{C}$ for 
7 days. Strain CNU004 ${ }^{\mathrm{T}}$ formed small, irregular, yellowpigmented colonies on MA plates after 4 days incubation. The strain was preserved at $-80{ }^{\circ} \mathrm{C}$ in marine broth 2216 (MB; Difco) supplemented with $20 \%$ glycerol (v/v).

Genomic DNA was extracted and purified by using the Wizard genomic DNA purification kit (Promega) according to the manufacturer's instructions, and the nearly complete 16S rRNA gene (1517 bp) was amplified by using bacterial universal primers (Johnson, 1994). The 16S rRNA gene fragment was sequenced directly by using a BigDye Terminator version 3.1 cycle sequencing kit and an ABI 3730xl automated DNA sequencer (Applied Biosystems).

The 16S rRNA gene sequence of strain $\mathrm{CNU}_{004}{ }^{\mathrm{T}}$ was compared with those available in GenBank via the BLAST program (http://www.ncbi.nlm.nih.gov/blast/) to determine an approximate phylogenetic affiliation, and the gene sequence was then aligned with those of closely related species by using the CLUSTAL $\mathrm{W}$ software program (Thompson et al., 1994). Sequence similarity values were computed by using Similarity Matrix version 1.1 (Ribosomal Database Project II, http://rdp.cme.msu.edu/ index.jsp; Cole et al., 2003) and the EzTaxon server (http:// www.eztaxon.org/; Chun et al., 2007). Gaps at the 5' and 3' ends of the alignment were omitted from further analyses. Phylogenetic trees were constructed by using the neighbour-joining, maximum-likelihood and maximum-parsimony algorithms available in the PHYLIP software, version 3.6 (Felsenstein, 2002). Evolutionary distance matrices were calculated according to the algorithm of Kimura's two-parameter model for the neighbour-joining method. Bootstrap analysis (1000 replications) was performed, by using the neighbour-joining method in the PHYLIP package, to evaluate the stability of the phylogenetic tree.
The neighbour-joining tree (Fig. 1) showed that strain CNU004 ${ }^{\mathrm{T}}$ forms a branch related to but distinct from the genera Formosa, Bizionia, Algibacter, Psychroserpens, Winogradskyella, Tamlana, Marinifexile, Gaetbulibacter, Yeosuana and Gelidibacter. The distinct phylogenetic position of strain $\mathrm{CNU}_{004}{ }^{\mathrm{T}}$ was confirmed in the maximum-likelihood and maximum-parsimony trees (not shown). Levels of pairwise 16S rRNA gene sequence similarity between strain CNU004 ${ }^{\mathrm{T}}$ and the type strains of members of related genera were $\leqslant 93.9 \%$. Strain CNU004 ${ }^{\mathrm{T}}$ exhibited 16S rRNA gene sequence similarities of 93.8$93.9 \%$ to its nearest phylogenetic neighbours, members of the genera Gaetbulibacter, Yeosuana and Algibacter.

Cell morphology and the presence of flagella were investigated by light microscopy (FDX-35; Nikon) and transmission electron microscopy (JEM100; JEOL) by using cells grown on $\mathrm{MA}$ at $30^{\circ} \mathrm{C}$ for 4 days. Gliding motility was assessed on $0.1 \times \mathrm{MA}$ (containing $10 \% \mathrm{MB}$ and $1 \%$ agar) plates (Bowman, 2000) by using the hanging-drop method (Bernardet et al., 2002). The Gram reaction was examined by using the bioMérieux Gram stain kit according to the manufacturer's instructions. Growth at $5,10,15,20,25,30,35$ and $40{ }^{\circ} \mathrm{C}$ was measured on MA, while growth at $\mathrm{pH} 3,4,5,5.5,6,6.5,7,7.5,8,8.5,9,9.5$, $10,10.5$ and 11 and tolerance of $1,1.5,2,2.5,3,3.5,4,5,6$ and $7 \%(\mathrm{w} / \mathrm{v}) \mathrm{NaCl}$ were measured in $\mathrm{MB}$. Tolerance of sea salts and artificial seawater was determined on trypticase soy agar (TSA; Difco) supplemented with $0-12 \%(\mathrm{w} / \mathrm{v}$; $1 \%$ intervals) sea salts (Sigma) and 10-200\% (v/v) artificial seawater (Yoon et al., 2002). Growth with $\mathrm{NaCl}$ as the sole salt was studied on TSA supplemented with 0$12 \%(\mathrm{w} / \mathrm{v}) \mathrm{NaCl}$. Anaerobic growth was assessed on MA incubated in a GasPak anaerobic system (BBL) for 7 days at $30{ }^{\circ} \mathrm{C}$. The presence of catalase activity was revealed by the production of oxygen bubbles by the cells when mixed with

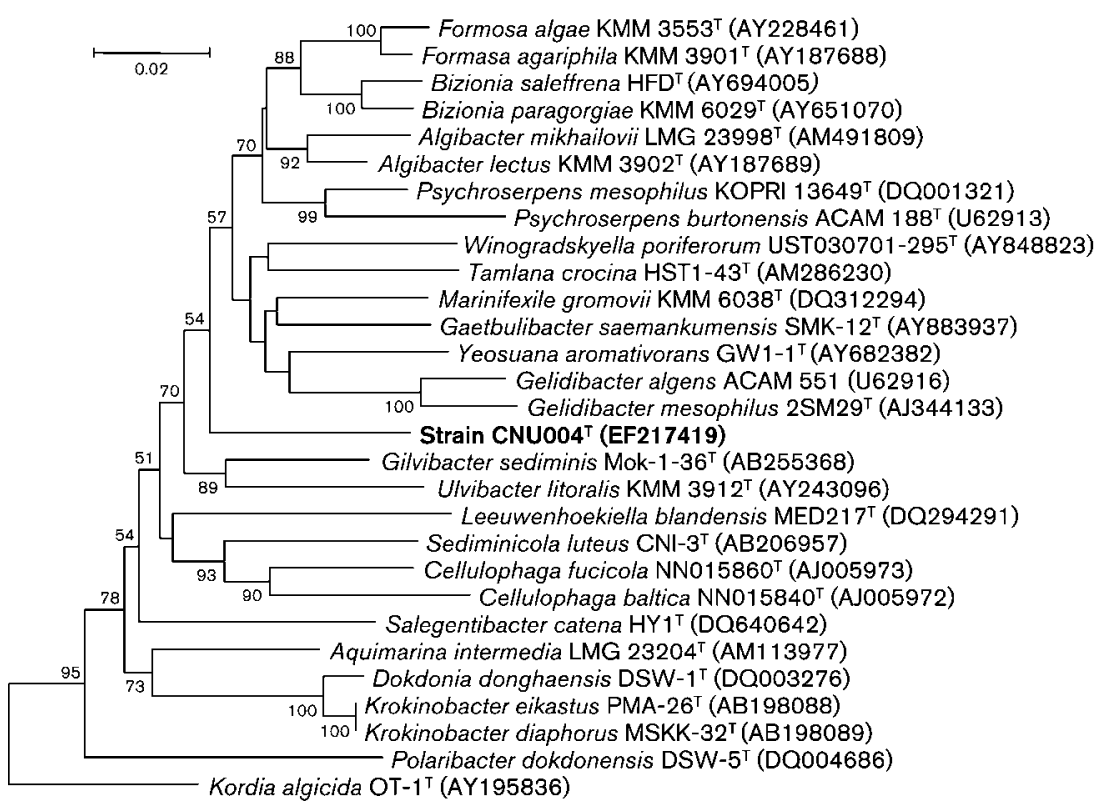

Fig. 1. Neighbour-joining phylogenetic tree based on 16S rRNA gene sequences, showing the relationships between strain $\mathrm{CNUOO}^{\top}$ and related taxa. Bootstrap percentages (based on 1000 replicates) $>50 \%$ are shown at branching points. The sequence of Brumimicrobium glaciale ACAM $644^{\top}$ (GenBank accession no. AF521195) was used as an outgroup (not shown). Bar, 0.02 changes per nucleotide position. 
$3 \%(\mathrm{v} / \mathrm{v}) \mathrm{H}_{2} \mathrm{O}_{2}$ on a glass slide. Oxidase activity was determined based on oxidation of $1 \%(\mathrm{w} / \mathrm{v}) \quad N, N, N^{\prime}, N^{\prime}-$ tetramethyl-p-phenylenediamine solution. DNase activity was examined by using DNase test agar with methyl green (Difco) supplemented with $2 \%(\mathrm{w} / \mathrm{v})$ sea salts (Sigma). Hydrolysis of casein, starch and Tween 80 was tested on MA by using the substrate concentrations given by Cowan \& Steel (1965). Hydrolysis of agar and CM-cellulose was investigated as described by Cowan \& Steel (1993). Hydrolysis of aesculin, gelatin and urea and reduction of nitrate were investigated as described by Lányí (1987) by using media supplemented with $2 \%(\mathrm{w} / \mathrm{v})$ sea salts. $\mathrm{H}_{2} \mathrm{~S}$ production was tested as described by Bruns et al. (2001). Other biochemical tests were performed by using API 20NE and API 20E kits (bioMérieux). Enzyme activities were tested by using an API ZYM kit (bioMérieux) following the manufacturer's instructions. API strips were inoculated with a heavy bacterial suspension in artificial seawater (Yoon et al., 2002) and were incubated at $30{ }^{\circ} \mathrm{C}$ for $96 \mathrm{~h}$. The biochemical, physiological and morphological characteristics of strain $\mathrm{CNU} 004^{\mathrm{T}}$ are given in the genus and species descriptions below and in Table 1 .

The presence of flexirubin-type pigments was investigated as described by Bernardet et al. (2002). Carotenoids in acetone extracts were detected spectroscopically by using a Shimadzu UV-visible spectrophotometer (model UV1650PC). Carotenoid composition was characterized by using HPLC-MS (LCMS-2010EV; Shimadzu) with a ShimPack FC-ODS $(150 \times 4.6 \mathrm{~mm}, 5-\mu \mathrm{m}$ particle size; column temperature $35{ }^{\circ} \mathrm{C}$ ) and acetonitrile/methanol/tetrahydrofuran $(5.8: 3.5: 0.7)$ as the mobile phase at a flow rate of $0.8 \mathrm{ml} \mathrm{min}^{-1}$. Zeaxanthin was identified based on its retention time, absorption spectrum and molecular mass. Commercial zeaxanthin (DHI; Water \& Environment) was used as a standard. Flexirubin-type pigments were absent. The yellow pigments of strain CNU004 ${ }^{\mathrm{T}}$ were identified as carotenoids, among which zeaxanthin was predominant.

Cellular fatty acid methyl esters were prepared from cultures grown on $\mathrm{MA}$ at $30{ }^{\circ} \mathrm{C}$ for 4 days and were analysed by the Korean Culture Center of Microorganisms (KCCM; Seoul, Republic of Korea) by using the MIDI Microbial Identification System. The three closest relatives of strain $\mathrm{CNU}^{2} 04^{\mathrm{T}}$, Gaetbulibacter saemankumensis KCTC $12379^{\mathrm{T}}$, Yeosuana aromativorans JCM $12862^{\mathrm{T}}$ and Algibacter mikhailovii LMG $23998^{\mathrm{T}}$, were grown under the same conditions and were included in the fatty acid analysis. The DNA G $+\mathrm{C}$ content and respiratory quinones were also analysed by the KCCM, by using reversed-phased HPLC (Komagata \& Suzuki, 1987).

The dominant fatty acids of strain CNU004 ${ }^{\mathrm{T}}$ were iso$\mathrm{C}_{15: 0}\left(18.4 \%\right.$ of the total), iso- $\mathrm{C}_{15: 1} \mathrm{G}(17.7 \%)$, iso- $\mathrm{C}_{17: 0}$ $3-\mathrm{OH}(16.6 \%)$ and iso- $\mathrm{C}_{15: 0} 3-\mathrm{OH}(11.6 \%)$. The detailed fatty acid profile of strain $\mathrm{CNU}_{004^{\mathrm{T}}}$ is compared with

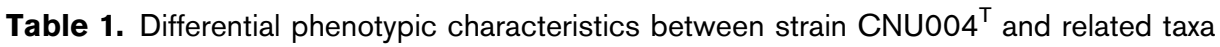

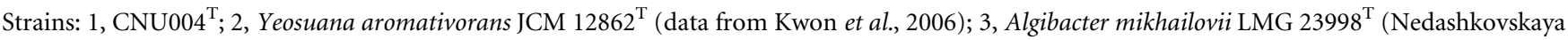
et al., 2007); 4, Gaetbulibacter saemankumensis KCTC $12379^{\mathrm{T}}$ (Jung et al., 2005). +, Positive; -, negative; ND, no data available.

\begin{tabular}{|c|c|c|c|c|}
\hline Characteristic & 1 & 2 & 3 & 4 \\
\hline Pigmentation & Yellow & Yellowish brown & Pale yellow & Yellow \\
\hline Gliding motility & - & - & + & + \\
\hline \multicolumn{5}{|l|}{ Ranges (optima) for growth } \\
\hline $\mathrm{NaCl}(\%, \mathrm{w} / \mathrm{v})$ & $0.5-4.5(2-3)$ & $0.5-4.0(2)$ & $1-6(2-3)$ & $0-7(2-3)$ \\
\hline Temperature $\left({ }^{\circ} \mathrm{C}\right)$ & $15-35(30-35)$ & $23-39(33-36)$ & $4-37(23-25)$ & $13-40(25-30)$ \\
\hline $\mathrm{pH}$ & $5.5-9.5(7.0-8.0)$ & $5-8(7)$ & $\mathrm{ND}$ & $\geqslant 5.5(7.0-8.0)$ \\
\hline \multicolumn{5}{|l|}{ Requirement for: } \\
\hline Oxygen & + & + & + & - \\
\hline Sea salts & + & + & $\mathrm{ND}$ & - \\
\hline \multicolumn{5}{|l|}{ Production of: } \\
\hline Oxidase & + & - & + & + \\
\hline Nitrate reductase & - & - & + & + \\
\hline Acid from carbohydrates & - & - & - & + \\
\hline \multicolumn{5}{|l|}{ Hydrolysis of: } \\
\hline Aesculin & + & ND & + & - \\
\hline Agar & - & - & + & ND \\
\hline DNA & - & ND & + & ND \\
\hline Gelatin & + & + & + & - \\
\hline Starch & - & - & - & + \\
\hline DNA G + C content $(\mathrm{mol} \%)$ & 37.7 & 51.4 & 35.1 & $34.7-34.9^{*}$ \\
\hline Major menaquinone(s) & MK-6 & MK-5, MK-6 & $\mathrm{ND}$ & MK-6 \\
\hline
\end{tabular}

${ }^{\star}$ Range of values for three strains, including the type strain. 
those of closely related members of the family Flavobacteriaceae in Table 2. The DNA G $+\mathrm{C}$ content of strain $\mathrm{CNU}_{004}{ }^{\mathrm{T}}$ was $37.7 \mathrm{~mol} \%$ and its major respiratory quinone was menaquinone- 6 .

Based on the results of $16 \mathrm{~S}$ rRNA gene sequence analysis and on phenotypic characteristics, we conclude that strain CNU004 ${ }^{\mathrm{T}}$ represents a novel species of a new genus in the family Flavobacteriaceae, for which the name Hyunsoonleella jejuensis gen. nov., sp. nov. is proposed.

\section{Description of Hyunsoonleella gen. nov.}

Hyunsoonleella (Hy.un.soon.le.el'la. L. dim. ending -ella; N.L. fem. n. Hyunsoonleella named after Hyun-Soon Lee, a Korean microbiologist who devoted her life to the study of photosynthetic bacteria).

Cells are strictly aerobic, Gram staining-negative, yellowpigmented, non-flagellated and rod-shaped. Gliding motility

Table 2. Cellular fatty acid content of strain $\mathrm{CNU} 004^{\top}$ and closely related taxa

Strains: 1, CNU004 ${ }^{\mathrm{T}}$; 2, Yeosuana aromativorans JCM $12862^{\mathrm{T}}$; 3, Algibacter mikhailovii LMG $23998^{\mathrm{T}}$; 4, Gaetbulibacter saemankumensis KCTC $12379^{\mathrm{T}}$. Values are percentages of the total fatty acids. Fatty acids amounting to $<1 \%$ of the total in all strains listed are not shown. All data are from the present study.

\begin{tabular}{|c|c|c|c|c|}
\hline Fatty acid & 1 & 2 & 3 & 4 \\
\hline \multicolumn{5}{|l|}{ Saturated } \\
\hline $\mathrm{C}_{15: 0}$ & 2.0 & 4.3 & - & 3.4 \\
\hline $\mathrm{C}_{16: 0}$ & 1.2 & 1.2 & 1.7 & 2.3 \\
\hline \multicolumn{5}{|l|}{ Branched saturated } \\
\hline iso- $\mathrm{C}_{13: 0}$ & - & - & - & 1.8 \\
\hline iso- $\mathrm{C}_{15: 0}$ & 18.4 & 20.1 & 13.2 & 23.1 \\
\hline anteiso- $\mathrm{C}_{15: 0}$ & 4.6 & 13.7 & 11.0 & 6.2 \\
\hline \multicolumn{5}{|l|}{ Monounsaturated } \\
\hline $\mathrm{C}_{15: 1} \omega 6 c$ & - & - & 6.9 & - \\
\hline $\mathrm{C}_{16: 1} \omega 5 c$ & - & 8.1 & - & - \\
\hline $\mathrm{C}_{17: 1} \omega 6 c$ & - & - & 4.3 & 1.0 \\
\hline \multicolumn{5}{|c|}{ Branched monounsaturated } \\
\hline anteiso- $\mathrm{C}_{15: 1}$ & 3.1 & - & - & - \\
\hline iso- $\mathrm{C}_{15: 1} \mathrm{G}$ & 17.7 & 5.1 & 10.6 & 5.9 \\
\hline iso- $\mathrm{C}_{15: 1} \omega 10 c$ & - & 6.8 & - & - \\
\hline iso- $\mathrm{C}_{17: 1} \omega 9 c$ & - & - & - & 1.7 \\
\hline \multicolumn{5}{|l|}{ Hydroxy } \\
\hline $\mathrm{C}_{15: 0} 2-\mathrm{OH}$ & 1.4 & 1.0 & 1.9 & 1.0 \\
\hline $\mathrm{C}_{17: 0} 2-\mathrm{OH}$ & 3.0 & 1.2 & 1.2 & 2.1 \\
\hline $\mathrm{C}_{15: 0} 3-\mathrm{OH}$ & - & - & 1.9 & - \\
\hline $\mathrm{C}_{16: 0} 3-\mathrm{OH}$ & - & - & 1.3 & - \\
\hline iso- $\mathrm{C}_{15: 0} 3-\mathrm{OH}$ & 11.6 & 2.2 & 4.9 & 5.3 \\
\hline iso- $\mathrm{C}_{16: 0} 3-\mathrm{OH}$ & 6.1 & 1.0 & 2.0 & 1.4 \\
\hline iso- $\mathrm{C}_{17: 0} 3-\mathrm{OH}$ & 16.6 & 5.9 & 6.9 & 17.9 \\
\hline Summed feature $3^{*}$ & 5.0 & 6.1 & 7.0 & 7.2 \\
\hline
\end{tabular}

*Summed features are groups of two or three fatty acids that cannot be separated by the MIDI system. Summed feature 3 comprised iso$\mathrm{C}_{15: 0} 2-\mathrm{OH}$ and/or $\mathrm{C}_{16: 1} \omega 7 c$. is not observed. Oxidase- and catalase-positive. Cells produce non-diffusible carotenoid pigments but flexirubin-type pigments are absent. The major respiratory quinone is menaquinone-6. The cellular fatty acid composition is dominated by branched saturated, branched monounsaturated and hydroxy components. As determined by $16 \mathrm{~S}$ rRNA gene sequence analysis, the genus Hyunsoonleella is a member of the family Flavobacteriaceae. The type species is Hyunsoonleella jejuensis.

\section{Description of Hyunsoonleella jejuensis sp. nov.}

Hyunsoonleella jejuensis (je.ju.en'sis. N.L. fem. adj. jejuensis pertaining to Jeju Island in the Republic of Korea, from where the type strain was isolated).

Displays the following characteristics in addition to those given for the genus. Cells are $0.3-0.6 \mu \mathrm{m}$ wide and 1.8$2.2 \mu \mathrm{m}$ long. After 4 days on MA, colonies are $1.0-1.5 \mathrm{~mm}$ in diameter, convex and circular with slightly irregular edges. Cells contain non-diffusible yellow carotenoid pigments with zeaxanthin as the major component. Growth occurs at $15.0-35.0{ }^{\circ} \mathrm{C}$ (optimum, 30.0-35.0 ${ }^{\circ} \mathrm{C}$ ) and at pH 5.5-9.5 (optimum, pH 7.0-8.0). $\mathrm{Na}^{+}$alone does not support growth. Requires sea salts or artificial seawater for growth. Grows on TSA supplemented with 3$7 \%(\mathrm{w} / \mathrm{v})$ sea salts or $20-180 \%(\mathrm{v} / \mathrm{v})$ artificial seawater. Grows on MB supplemented with $0-1.5 \%(w / v) ~ \mathrm{NaCl}$. Aesculin, Tween 80, gelatin and CM-cellulose are hydrolysed, but agar, DNA, casein, starch and urea are not. Acetoin is produced, but indole and $\mathrm{H}_{2} \mathrm{~S}$ are not. Nitrate is not reduced. Tryptophan deaminase, lysine decarboxylase and ornithine decarboxylase activities are absent. Acid is not produced from glucose, mannitol, inositol, sorbitol, rhamnose, sucrose, melibiose, amygdalin or arabinose. Turanose, mannose, mannitol, gluconate, adipic acid and malate are assimilated, but arabinose, glucose, maltose, $\mathrm{N}$ acetylglucosamine, capric acid, trisodium citrate and phenylacetic acid are not. In the API ZYM system, positive for alkaline phosphatase, esterase (C4), esterase lipase (C8), leucine arylamidase, valine arylamidase, cystine arylamidase, trypsin, acid phosphatase, $\alpha$-galactosidase, $\beta$-galactosidase and $N$-acetyl- $\beta$-glucosaminidase, and weakly positive for naphthol-AS-BI-phosphohydrolase; negative for lipase (C14), $\alpha$-chymotrypsin, $\beta$-glucuronidase, $\alpha$ glucosidase, $\beta$-glucosidase, $\alpha$-mannosidase and $\alpha$-fucosidase. The major fatty acids are iso- $\mathrm{C}_{15: 0}$, iso- $\mathrm{C}_{15: 1} \mathrm{G}$, iso$\mathrm{C}_{17: 0} 3-\mathrm{OH}$ and iso- $\mathrm{C}_{15: 0} 3-\mathrm{OH}$. The DNA G $+\mathrm{C}$ content of the type strain is $37.7 \mathrm{~mol} \%$.

The type strain, CNU004 ${ }^{\mathrm{T}}\left(=\mathrm{KCTC} 22242^{\mathrm{T}}=\mathrm{DSM}\right.$ $\left.21035^{\mathrm{T}}\right)$, was isolated from seawater off Jeju Island, Republic of Korea.

\section{References}

Alcantara, S. \& Sanchez, S. (1999). Influence of carbon and nitrogen sources on Flavobacterium growth and zeaxanthin biosynthesis. J Ind Microbiol Biotechnol 23, 697-700. 
Asker, D., Beppu, T. \& Ueda, K. (2007). Zeaxanthinibacter enoshimensis gen. nov., sp. nov., a novel zeaxanthin-producing marine bacterium of the family Flavobacteriaceae, isolated from seawater off Enoshima Island, Japan. Int J Syst Evol Microbiol 57, 837-843.

Bernardet, J.-F. \& Nakagawa, Y. (2006). An introduction to the family Flavobacteriaceae. In The Prokaryotes. A Handbook on the Biology of Bacteria, 3rd edn, vol. 7, pp. 455-480. Edited by M. Dworkin, S. Falkow, E. Rosenberg, K. H. Schleifer \& E. Stackebrandt. New York: Springer.

Bernardet, J. F., Nakagawa, Y. \& Holmes, B. (2002). Proposed minimal standards for describing new taxa of the family Flavobacteriaceae and emended description of the family. Int J Syst Evol Microbiol 52, 1049-1070.

Berry, A., Janssens, D., Hümbelin, M., Jore, J. P. M., Hoste, B., Cleenwerck, I., Vancanneyt, M., Bretzel, W., Mayer, A. F. \& other authors (2003). Paracoccus zeaxanthinifaciens sp. nov., a zeaxanthinproducing bacterium. Int J Syst Evol Microbiol 53, 231-238.

Bowman, J. P. (2000). Description of Cellulophaga algicola sp. nov., isolated from the surfaces of Antarctic algae, and reclassification of Cytophaga uliginosa (ZoBell and Upham 1944) Reichenbach 1989 as Cellulophaga uliginosa comb. nov. Int J Syst Evol Microbiol50, 1861-1868.

Bowman, J. P. \& Nichols, D. S. (2002). Aequorivita gen. nov., a member of the family Flavobacteriaceae isolated from terrestrial and marine Antarctic habitats. Int J Syst Evol Microbiol 52, 1533-1541.

Bowman, J. P. \& Nichols, D. S. (2005). Novel members of the family Flavobacteriaceae from Antarctic maritime habitats including Subsaximicrobium wynnwilliamsii gen. nov., sp. nov., Subsaximicrobium saxinquilinus sp. nov., Subsaxibacter broadyi gen. nov., sp. nov., Lacinutrix copepodicola gen. nov., sp. nov., and novel species of the genera Bizionia, Gelidibacter and Gillisia. Int J Syst Evol Microbiol 55, 1471-1486.

Bowman, J. P., McCammon, S. A., Brown, J. L., Nichols, P. D. \& McMeekin, T. A. (1997). Psychroserpens burtonensis gen. nov., sp. nov., and Gelidibacter algens gen. nov., sp. nov., psychrophilic bacteria isolated from Antarctic lacustrine and sea ice habitats. Int J Syst Bacteriol 47, 670-677.

Bowman, J. P., McCammon, S. A., Lewis, T., Skerratt, J. H., Brown, J. L., Nichols, D. S. \& McMeekin, T. A. (1998). Psychroflexus torquis gen. nov., sp. nov., a psychrophilic species from Antarctic sea ice, and reclassification of Flavobacterium gondwanense (Dobson et al. 1993) as Psychroflexus gondwanense gen. nov., comb. nov. Microbiology 144, 1601-1609.

Bruns, A., Rohde, M. \& Berthe-Corti, L. (2001). Muricauda ruestringensis gen. nov., sp. nov., a facultatively anaerobic, appendaged bacterium from German North Sea intertidal sediment. Int $J$ Syst Evol Microbiol 51, 1997-2006.

Cho, J.-C. \& Giovannoni, S. J. (2004). Robiginitalea biformata gen. nov., sp. nov., a novel marine bacterium in the family Flavobacteriaceae with a higher G + C content. Int J Syst Evol Microbiol 54, 1101-1106.

Chun, J., Lee, J.-H., Jung, Y., Kim, M., Kim, S., Kim, B. K. \& Lim, Y. W. (2007). EzTaxon: a web-based tool for the identification of prokaryotes based on $16 \mathrm{~S}$ ribosomal RNA gene sequences. Int J Syst Evol Microbiol 57, 2259-2261.

Cole, J. R., Chai, B., Marsh, T. L., Farris, R. J., Wang, Q., Kulam, S. A., Chandra, S., McGarrell, D. M., Schmidt, T. M. \& other authors (2003). The Ribosomal Database Project (RDP-II): previewing a new autoaligner that allows regular updates and the new prokaryotic taxonomy. Nucleic Acids Res 31, 442-443.

Cowan, S. T. \& Steel, K. J. (1965). Manual for the Identification of Medical Bacteria. London: Cambridge University Press.

Cowan, S. T. \& Steel, K. J. (1993). Manual for the Identification of Medical Bacteria, 3rd edn. Cambridge: Cambridge University Press.
Felsenstein, J. (2002). PHYLIP (phylogeny inference package), version 3.6a. Distributed by the author. Department of Genome Sciences, University of Washington, Seattle, USA.

Garrity, G. M. \& Holt, J. G. (2001). The road map to the Manual. In Bergey's Manual of Systematic Bacteriology, 2nd edn, vol. 1, pp. 119166. Edited by D. R. Boone, R. W. Castenholz \& G. M. Garrity. New York: Springer.

Hundle, B. S., O'Brien, D. A., Beyer, P., Kleinig, H. \& Hearst, J. E. (1993). In vitro expression and activity of lycopene cyclase and $\beta$ carotene hydroxylase from Erwinia herbicola. FEBS Lett 315, 329-334.

Johnson, J. L. (1994). Similarity analysis of rRNAs. In Methods for General and Molecular Bacteriology, pp. 683-700. Edited by P. Gerhardt, R. G. E. Murray, W. A. Wood \& N. R. Krieg. Washington, DC: American Society for Microbiology.

Jung, S.-Y., Kang, S.-J., Lee, M.-H., Lee, S.-Y., Oh, T.-K. \& Yoon, J.-H. (2005). Gaetbulibacter saemankumensis gen. nov., sp. nov., a novel member of the family Flavobacteriaceae isolated from a tidal flat sediment in Korea. Int J Syst Evol Microbiol 55, 1845-1849.

Komagata, K. \& Suzuki, K. (1987). Lipid and cell-wall analysis in bacterial systematics. Methods Microbiol 19, 161-207.

Kwon, K. K., Lee, H.-S., Jung, H.-B., Kang, J.-H. \& Kim, S.-J. (2006). Yeosuana aromativorans gen. nov., sp. nov., a mesophilic marine bacterium belonging to the family Flavobacteriaceae, isolated from estuarine sediment of the South Sea, Korea. Int J Syst Evol Microbiol 56, 727-732.

Lagarde, D., Beuf, L. \& Vermaas, W. (2000). Increased production of zeaxanthin and other pigments by application of genetic engineering techniques to Synechocystis sp. strain PCC 6803. Appl Environ Microbiol 66, 64-72.

Lányí, B. (1987). Classical and rapid identification methods for medically important bacteria. Methods Microbiol 19, 1-67.

Nedashkovskaya, O. I., Kim, S. B., Han, S. K., Lysenko, A. M., Rohde, M., Rhee, M.-S., Frolova, G. M., Falsen, E., Mikhailov, V. V. \& Bae, K. S. (2004). Maribacter gen. nov., a new member of the family Flavobacteriaceae, isolated from marine habitats, containing the species Maribacter sedimenticola sp. nov., Maribacter aquivivus sp. nov., Maribacter orientalis sp. nov. and Maribacter ulvicola sp. nov. Int J Syst Evol Microbiol 54, 1017-1023.

Nedashkovskaya, O. I., Vancanneyt, M., Kim, S. B., Hoste, B. \& Bae, K. S. (2007). Algibacter mikhailovii sp. nov., a novel marine bacterium of the family Flavobacteriaceae, and emended description of the genus Algibacter. Int J Syst Evol Microbiol 57, 2147-2150.

Nichols, C. M., Bowman, J. P. \& Guezennec, J. (2005). Olleya marilimosa gen. nov., sp. nov., an exopolysaccharide-producing marine bacterium from the family Flavobacteriaceae, isolated from the Southern Ocean. Int J Syst Evol Microbiol 55, 1557-1561.

Pinhassi, J., Bowman, J. P., Nedashkovskaya, O. I., Lekunberri, I., Gomez-Consarnau, L. \& Pedrós-Alió, C. (2006). Leeuwenhoekiella blandensis sp. nov., a genome-sequenced marine member of the family Flavobacteriaceae. Int J Syst Evol Microbiol 56, 1489-1493.

Reichenbach, H. (1989). The order Cytophagales Leadbetter 1974, $99^{\mathrm{AL}}$. In Bergey's Manual of Systematic Bacteriology, vol. 3, pp. 20112073. Edited by J. T. Staley, M. P. Bryant, N. Pfennig \& J. C. Holt. Baltimore: Williams \& Wilkins.

Thompson, J. D., Higgins, D. G. \& Gibson, T. J. (1994). CLUSTAL W: improving the sensitivity of progressive multiple sequence alignment through sequence weighting, position-specific gap penalties and weight matrix choice. Nucleic Acids Res 22, 4673-4680.

Yoon, J. H., Lee, K. C., Kho, Y. H., Kang, K. H., Kim, C. J. \& Park, Y. H. (2002). Halomonas alimentaria sp. nov., isolated from jeotgal, a traditional Korean fermented seafood. Int J Syst Evol Microbiol 52, 123-130. 